\title{
CALCULATION OF HEAT PRODUCTION FROM INSENSIBLE LOSS OF WEIGHT ${ }^{1}$
}

\author{
By MARGARET W. JOHNSTON AND L. H. NEWBURGH \\ (Department of Internal Medicine, the Medical School, University of Michigan, Ann Arbor)
}

(Received for publication January 23, 1942)

In a previous communication, Newburgh and his associates (1) proposed a method for calculating 24-hour heat production from I. W. ${ }^{2}$ rather than from I. L., ${ }^{2}$ since variations in respiratory quotient cause the relationship of I. W. to I. L. to vary from 85 to 100 per cent. However, in reviewing the literature recently, we were impressed with two characteristics of Levine and Marples' (2) prediction curve which they obtained when they plotted I. L. against heat production in 196 cases. These data were obtained by means of the Russel Sage calorimeter or with the respiration chamber at the New York Nursery and Child's Hospital. The two characteristics were, first, the almost constant percentage of heat removed by vaporization of water throughout the whole course of the line and, second, that the origin of the line is not far from zero.

Consequently, we decided to re-examine our own material to determine how closely heat production can be predicted from I. L. rather than from I. W.

The smoothed curve of Levine and Marples is reproduced in Figure 1. We have plotted 34 of our own experiments with 10 normal adults ${ }^{3}$ on this diagram. They consist of simultaneous determinations of I. L. and heat production for 24hour periods in the respiration chamber. Further experiments on 11 additional subjects ${ }^{3}$ were also included. Here we have used for the I. L. the average of many consecutive 24-hour periods. The average 24-hour heat production in this series was determined by feeding a carefully weighed constant diet that closely approached maintenance

1 The expense of this study was defrayed in part by a grant from the Horace $H$. and Mary A. Rackham School of Graduate Studies.

$2 \mathrm{I}$. W. is an abbreviation for the weight of water vaporized from skin and lungs. I. $L$. is an abbreviation for the insensible loss of weight.

8 These details of the methods and the biological data may be found in earlier publications from this laboratory $(1,3,4)$. as a result of preliminary trials. The 24-hour heat production was taken to be the energy of this diet, corrected for small changes in weight which occasionally occurred. In these experiments, the periods always exceeded one month. Further, it is important to note that these 11 subjects were leading their usual lives except that they were asked to avoid the feeling of chilliness or warmth by adjustment of clothing. Several single periods had to be excluded because these conditions could not be obtained.

Inspection of Figure 1 reveals that only 4 of our 45 points fall outside of the \pm 15 per cent limits, even though the line has been extended from about 2,000 to 3,500 calories. The average percentage of heat lost by vaporization for these subjects was 24.7 per cent. The percentage of heat lost by vaporization is not quite constant throughout Levine and Marples' line, as pointed out by Heller (5) who calculated that the percentage at the lower end was 27.6 and at the upper end, 24.2.

Since it seems probable that a constant percentage of heat is removed by vaporization of water throughout the whole range of environmental temperatures at which chilling and sweating can be prevented, we decided to draw a line which begins at zero I. L. and zero heat and whose slope throughout represents a loss of 24.5 per cent of total heat removed by vaporization. Since it is desired to express this relationship in terms of I. L. rather than as I. W., the latter needs to be converted to the former.

Consideration of Levine and Marples' prediction, where approximately 25 per cent of the heat was removed by vaporization of water, shows that close to 94 per cent of I. L. is water vapor. Further study of the data obtained in this laboratory, from normal individuals existing on usual mixed diets, gives a value of 93 per cent.

Hence our prediction line for normal human beings existing on usual mixed diets has also been 


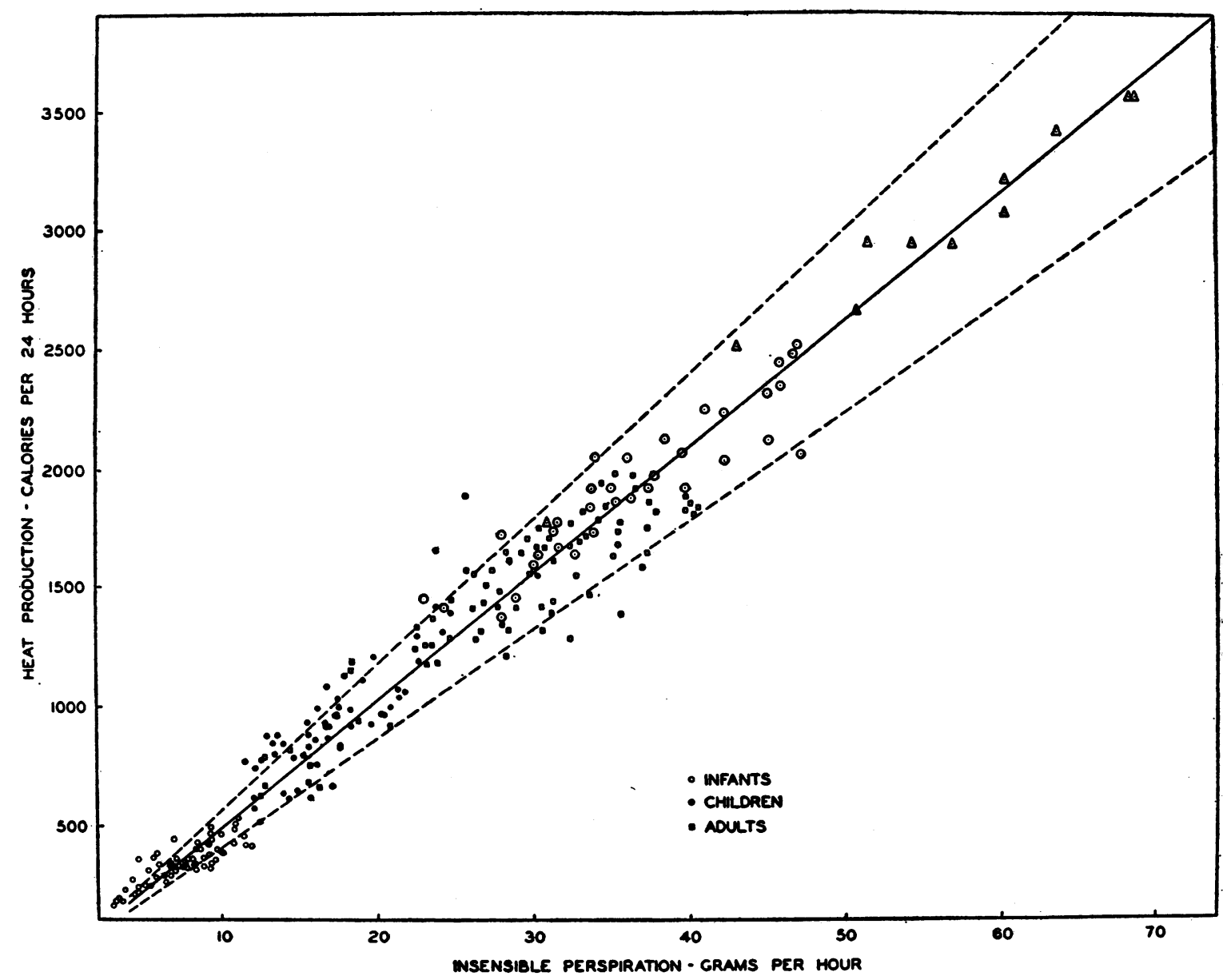

Fig. 1. Reproduction of Levine and Marples (2) Smoothed Curve on Which We Have Placed Our Own Data

Levine and Marples values are represented by $\bigcirc$ for infants, $\odot$ for children and $\square$ for adults. Our own data are represented by $\odot$ for simultaneous determination of I.L. and indirect calorimetry for 24 hours; and by $\Delta$ for I. L. and heat production calculated from diet and change in weight.

constructed so that I. W. is 93.5 per cent of I. L. (Figure 2, line A).

In Figure 2 also we have reproduced lines from several publications for purposes of comparison with our own prediction line. It will be seen that the smoothed curve of Levine and Marples (line B) is almost identical with ours (line A). It departs slightly at the lower end and this may well be due to the difficulty of dealing with infants. The data gathered by Ginandes and Topper (6), using children 4 to 15 years of age, are represented by line $C$. The I. L. was determined for periods of 2 to 3 hours and the heat production, by the Benedict-Roth apparatus, before or after the weighings. Their line is significantly below ours. This suggests that the I. L.s are somewhat high, due to restlessness on the part of children expected to remain perfectly quiet for so long a time. Had the heat production been determined in the middle of the weighings, higher values might have been recorded. On the other hand, Levine and Marples were able to obtain simultaneous records of I. L. and heat production.

Line D represents the prediction proposed by Benedict and Root (7) ; Jores' (8) data follow the same line. Here the percentage of heat lost by vaporization of water is not constant. It is 21.9 per cent at the lower end and 32.5 at the upper end. Furthermore, if one projects the curve downward, at 493 calories the I. L. would be zero. Perhaps this situation is attributable to 
the use of emaciated diabetics for low heat productions and of hyperthyroids for large heat productions. Furthermore, the I. L. was determined from 10 to 15 minute periods. Wiley and Newburgh (9) found that short periods gave irregular results even when trained normal subjects were employed. Jores followed the procedure proposed by Benedict and Root and his series also included a large amount of pathological material. The same criticism applies to the data of Laszlo and Schurmeyer (10) and to those of Heller (5).
However, Heller and Schwartz (11) analyzed 1936 cases studied in the respiration calorimeter taken from the early experiments of Atwater, followed by those of Benedict and of DuBois. They dealt with subjects in the basal state, with others after food, and with a third group during work. Heat productions beyond 4,000 calories were excluded. They derived an equation for the lines representing each of the three groups. When I. L. is plotted against heat there is a marked difference in the slope of each of the

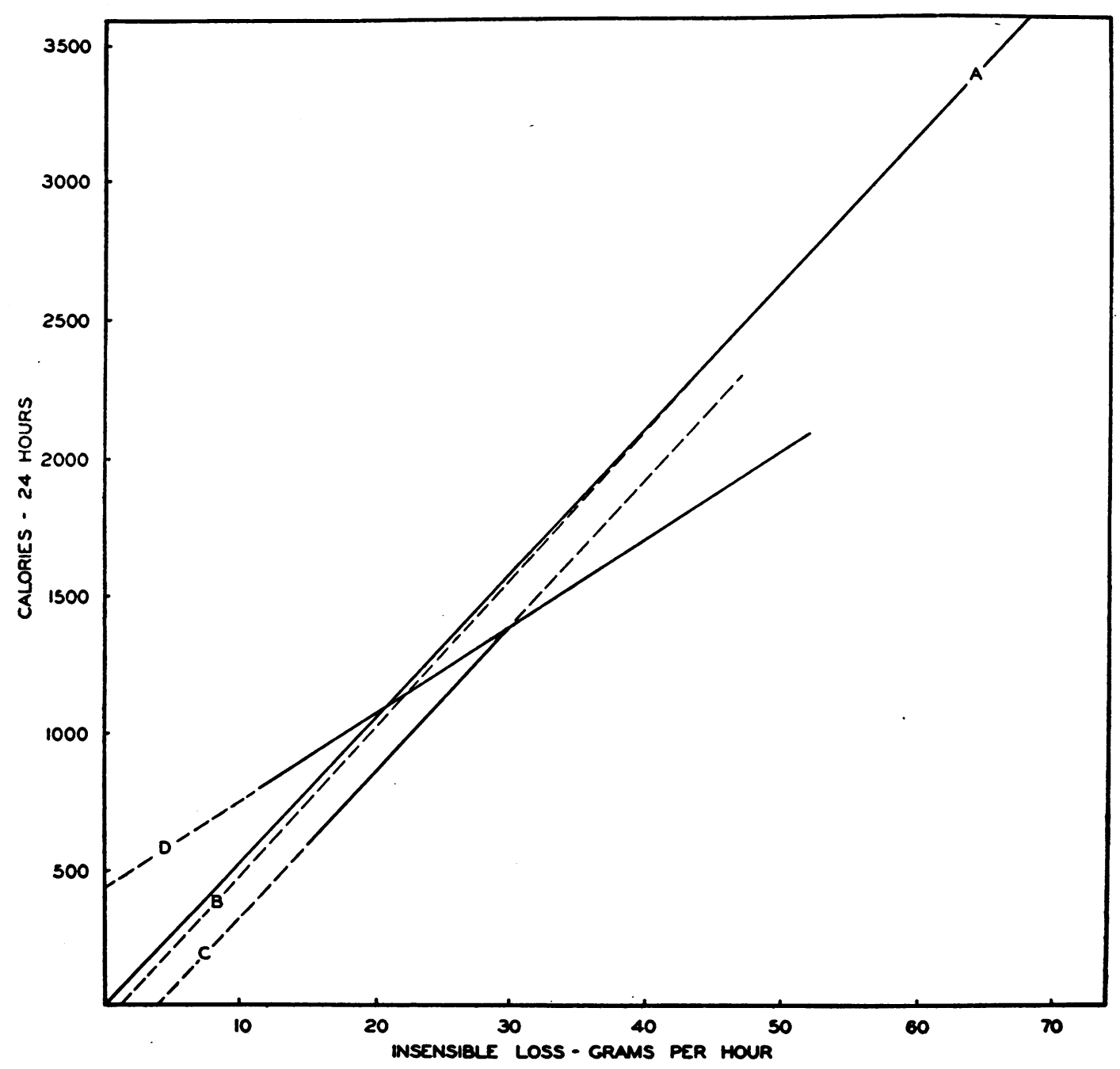

FIg. 2

Line A was constructed so that it represents a loss of 24.5 per cent of the heat by vaporization of water and so that $\frac{\text { I.W. }}{\text { I.L. }} \times 100=93.5$. Broken line $B$, Levine and Marples' (2) smoothed curve. Line C, Ginandes and Topper (6). Line D, Benedict and Root (7). 


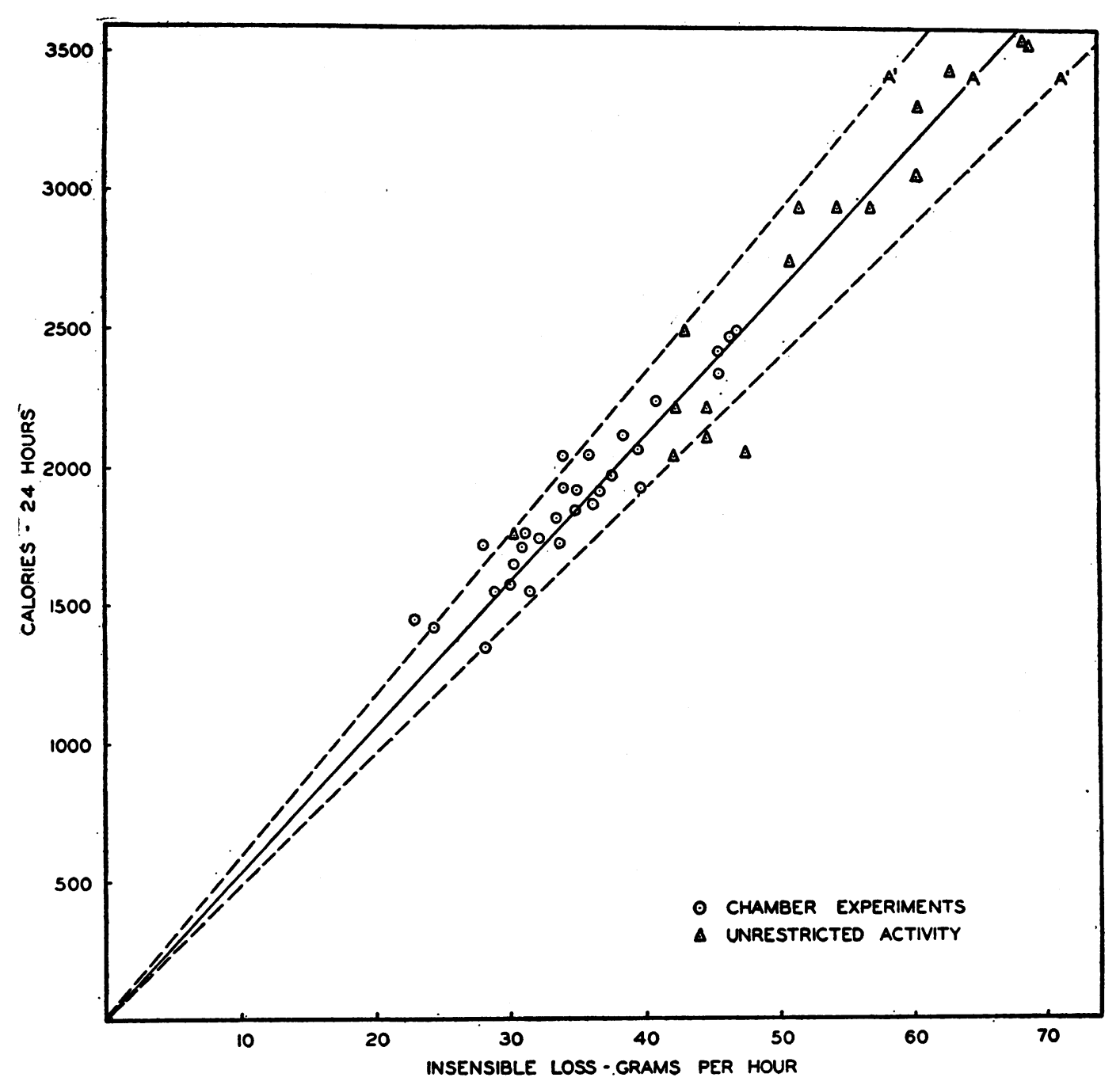

Fig. 3

Line $A$ same as Figure 2. Lines $A^{\prime}$ and $A^{\prime}$ represent a 10 per cent variation from line $A$.

lines and none is close to ours. However, the line ${ }^{4}$ representing all the cases has a slope identical with our prediction line. How much weight should be placed on this correlation is questionable. The subjects may have been chilly at times or may have perspired somewhat, since such details were not taken into account. That this was the case is suggested by the wide divergence of the maximal and minimal values for the water vapor from which the averages were calculated. Nevertheless the average may have considerable significance since the material is so extensive.

\footnotetext{
$4 y=1.9 x-0.2$, where $y$ is grams I. L. per hour and $x$ is heat production for 24 hours divided by 100 .
}

Finally we constructed Figure 3 on which line $A$ is our above described prediction line and lines $\mathrm{A}^{\prime}$ and $\mathrm{A}^{\prime}$ indicate 10 per cent variations from line $A$. We have plotted our 45 points on this diagram. Only 5 fall definitely outside the $A^{\prime}$ lines.

The 2 points on the lower side of the $\mathrm{A}^{\prime}$ lines are from a subject who was emotionally disturbed while in the chamber but the average of determinations made while he followed his usual occupation, falls strikingly close to the prediction line. ${ }^{5}$

\footnotetext{
s See subject R. L. G., Tables I and II.
} 
One ${ }^{6}$ of the 3 points more than 10 per cent above the prediction, is one of 11 measurements from the same subject. The other 10 fall well within the 10 per cent limits. The other 2 points ${ }^{7}$ are from subjects whose second determinations were within the 10 per cent limits.

A simple mathematical relationship must of necessity exist between the heat production and the insensible loss of weight, when the percentage of heat lost by the vaporization of water is constant (24.5 per cent) and when at the same time, the insensible water is a constant fraction of the total insensible loss of weight. The first condition may be satisfied by the careful training of the subject and the avoidance of high environmental temperatures; the second, by maintaining the individual on a constant diet of known composition. For example, since 1 gram water vaporized equals 0.58 calorie, the relationship between heat production for 24 hours and hourly insensible loss. when I. W. $=$ I. L. (low carbohydrate plan) may be expressed as follows:

(1) Heat production for 24 hours $=$ I. L. per hour $\times 24 \times 0.58 \times \frac{100}{24.5}$

Heat production for 24 hours $=$ I. L. per hour $\times 56.8$

On the other hand when high carbohydrate, supermaintenance diets are fed, the I. W. is close to 88 per cent of the I. L. and this relationship of heat production to I. L. is expressed thus:

(2) Heat production for 24 hours $=$ I. L. per hour $\times \frac{88}{100} \times 56.8$

Heat production for 24 hours $=I$. L. per hour $\times 50$

When, however, usual normal maintenance diets are fed so that the I. W. is 93.5 per cent of the I. L. the expression is

(3) Heat production per 24 hours $=$ I. L. per hour $\times \frac{93.5}{100} \times 56.8$

Heat production per 24 hours $=$ I. L. per hour $\times 53.1$

${ }^{6}$ See subject B. de V., Table I.

? See subjects McQ. and D. R., Table I.
Thus we have derived factors which, when multiplied by the hourly insensible loss of weight, give the heat production for 24 hours and for purpose of simplification, whole numbers may be used, i.e. 57 for the low carbohydrate diet, 53 for the normal and 50 for the high carbohydrate. For all ordinary plans, the factor 53 multiplied by the hourly insensible loss of weight obtained under carefully controlled conditions will give a satisfactory prediction of the 24-hour heat production.

It remains now to compare our earlier complicated calculation ${ }^{8}$ of heat production from I. L. with the simple prediction from hourly I. L. alone. Table I makes the comparisons in the 34 chamber experiments. It is obvious that heat production can be predicted as successfully by the simple method as by the complicated calculation.

Table II gives the simple prediction for the ambulatory group compared with their heat production calculated from the diet and change in weight. Since the first 3 subjects were diabetics on low carbohydrate diets, the factor 57 should be used. When this is done, the maximal variation for the whole group is 4 per cent.

\section{DISCUSSION}

It should be noted that our data are restricted to 24-hour periods. However, much of the mate-

8 The method of calculation has been discussed in a previous paper from this laboratory (1). For convenience it is briefly reproduced.

Calories $=4.1 \mathrm{C}+26.5 \mathrm{~N}+9.3 \mathrm{~F}$.

Carbohydrate of diet was assumed to be carbohydrate oxidized. It was further assumed that 25 per cent of the heat was lost by vaporization. Protein was calculated from urinary N. Fat was derived from the following equations :

I. $\mathrm{L} .=\mathrm{I}$. W. $+\mathrm{CO}_{2}-\mathrm{O}_{2}$

I. W. $\times 0.58 \times \frac{100}{25}=$ calories. $0.58 \times \frac{100}{25}=2.32$

I. $\mathrm{W} .=\frac{\text { calories }}{2.32}$

$\mathrm{CO}_{2}-\mathrm{O}_{2}=0.41 \mathrm{C}+0.84 \mathrm{~N}-0.08 \mathrm{~F}$

I. L. $=\frac{4.1 \mathrm{C}+26.5 \mathrm{~N}+9.3 \mathrm{~F}}{2.32}+0.41 \mathrm{C}+0.84 \mathrm{~N}-0.08 \mathrm{~F}$

I. $\mathrm{L} .=2.18 \mathrm{C}+12.26 \mathrm{~N}+3.93 \mathrm{~F}$

F. $=\frac{\text { I. L. }-(2.18 \mathrm{C}+12.26 \mathrm{~N})}{3.93}$

The calories of the M.M. (metabolic mixture) were increased by the heat transferred to food to get heat production. 
MARGARET W. JOHNSTON AND L. H. NEWBURGH

TABLE I

Comparison of heat production calculated from I.W. and from I.L. with

that determined by indirect calorimetry for 24 hour periods

\begin{tabular}{|c|c|c|c|c|c|c|c|c|}
\hline \multirow{3}{*}{ Date } & \multirow{3}{*}{ Subject } & \multirow{3}{*}{ I.L. } & \multicolumn{5}{|c|}{ Heat production } & \multirow{3}{*}{$\begin{array}{l}\text { Heat lost by } \\
\text { vaporization }\end{array}$} \\
\hline & & & \multirow{2}{*}{$\begin{array}{c}\text { Indirect } \\
\text { calorimetry }\end{array}$} & \multicolumn{4}{|c|}{ From I.L. } & \\
\hline & & & & $\begin{array}{l}\text { Calories } \\
\text { M.M.8 }\end{array}$ & $\begin{array}{l}\text { Difference } \\
\text { columns } \\
4 \text { and } 5\end{array}$ & $\begin{array}{c}\text { Calories } \\
\text { I.L. X53" }\end{array}$ & $\begin{array}{l}\text { Difference } \\
\text { columns } \\
4 \text { and } 7\end{array}$ & \\
\hline 1935 & & $\underset{\substack{\text { grams per } \\
\text { her }}}{ }$ & & & per cent & & per cent & $\begin{array}{l}\text { per cent } \\
\text { of total }\end{array}$ \\
\hline \begin{tabular}{l} 
January 14 \\
February 24 \\
March 24 \\
March 31 \\
November 24 \\
November 28 \\
December 8 \\
December 23 \\
\multicolumn{1}{c}{1936}
\end{tabular} & $\begin{array}{l}\text { B.deV. } \\
\text { B.deV } \\
\text { B.deV. } \\
\text { B.deV. } \\
\text { B.deV. } \\
\text { B.deV. } \\
\text { B.deV. } \\
\text { B.deV. }\end{array}$ & $\begin{array}{l}31.5 \\
30.9 \\
34 . \\
36 . \\
34 . \\
33.6 \\
37 . \\
41 .\end{array}$ & $\begin{array}{l}1772 \\
1729 \\
2059 \\
2065 \\
1929 \\
1828 \\
1925 \\
2242\end{array}$ & $\begin{array}{l}1634 \\
1696 \\
1827 \\
1928 \\
1755 \\
1725 \\
2035 \\
2134\end{array}$ & $\begin{array}{r}-7.7 \\
-1.9 \\
-11.3 \\
-6.5 \\
-9.0 \\
-5.6 \\
+5.4 \\
-4.7\end{array}$ & $\begin{array}{l}1670 \\
1640 \\
1804 \\
1908 \\
1804 \\
1780 \\
1960 \\
2172\end{array}$ & $\begin{array}{r}-5.3 \\
-5.2 \\
-12.4 \\
-7.6 \\
-6.5 \\
-2.6 \\
+1.8 \\
-3.1\end{array}$ & $\begin{array}{l}24.2 \\
24.5 \\
23.2 \\
22.6 \\
23.7 \\
23.3 \\
25.4 \\
23.7\end{array}$ \\
\hline \begin{tabular}{l} 
February 2 \\
February 4 \\
February 28 \\
March 21 \\
\multicolumn{1}{c}{1935}
\end{tabular} & $\begin{array}{l}\text { B.deV. } \\
\text { B.deV. } \\
\text { McQ. } \\
\text { McQ. }\end{array}$ & $\begin{array}{l}39.7 \\
45.7 \\
31.5 \\
28 .\end{array}$ & $\begin{array}{l}2079 \\
2430 \\
1567 \\
1725\end{array}$ & $\begin{array}{l}2054 \\
2531 \\
1743 \\
1537\end{array}$ & $\begin{array}{r}-1.2 \\
+4.2 \\
+11.2 \\
-10.9\end{array}$ & $\begin{array}{l}2105 \\
2420 \\
1670 \\
1485\end{array}$ & $\begin{array}{r}+1.3 \\
-0.4 \\
+6.6 \\
-13.9\end{array}$ & $\begin{array}{l}24.6 \\
24.4 \\
27.7 \\
23.4\end{array}$ \\
\hline $\begin{array}{l}\text { April } 22 \\
\text { December } 26\end{array}$ & $\begin{array}{l}\text { W.M. } \\
\text { W.M. }\end{array}$ & $\begin{array}{l}38.5 \\
46.5\end{array}$ & $\begin{array}{l}2124 \\
2486\end{array}$ & $\begin{array}{l}2124 \\
2596\end{array}$ & $\begin{array}{l} \pm 0.0 \\
+4.2\end{array}$ & $\begin{array}{l}2040 \\
2465\end{array}$ & $\begin{array}{l}-3.9 \\
-0.8\end{array}$ & $\begin{array}{l}26.0 \\
26.0\end{array}$ \\
\hline $\begin{array}{l}\text { January } 2 \\
\text { January } 12\end{array}$ & $\begin{array}{l}\text { W.M.M. } \\
\text { W.M. }\end{array}$ & $\begin{array}{l}45.9 \\
46.8\end{array}$ & $\begin{array}{l}2346 \\
2501\end{array}$ & $\begin{array}{l}2434 \\
2493\end{array}$ & $\begin{array}{l}+3.8 \\
-0.3\end{array}$ & $\begin{array}{l}2432 \\
2480\end{array}$ & $\begin{array}{l}+3.7 \\
-0.8\end{array}$ & $\begin{array}{l}26.7 \\
25.0\end{array}$ \\
\hline $\begin{array}{l}\text { October } 10 \\
\text { November } 6 \\
\text { November } 12 \\
\text { November } 19 \\
\text { November } 21 \\
\text { December } 5 \\
\text { December } 12 \\
\text { December } 19 \\
1936\end{array}$ & $\begin{array}{l}\text { J.S. } \\
\text { J.S. } \\
\text { J.S. } \\
\text { J.S. } \\
\text { R.L.G. } \\
\text { R.L.G. } \\
\text { R.L.G. } \\
\text { R.L.G. }\end{array}$ & $\begin{array}{l}39.7 \\
37.8 \\
36.2 \\
35 . \\
45.2 \\
45 . \\
42.3 \\
42.3\end{array}$ & $\begin{array}{l}1935 \\
1987 \\
1889 \\
1924 \\
2110 \\
2215 \\
2054 \\
2229\end{array}$ & $\begin{array}{l}2196 \\
2059 \\
1876 \\
1808 \\
2387 \\
2344 \\
2358 \\
2353\end{array}$ & $\begin{array}{r}+13.5 \\
+3.1 \\
-0.7 \\
-6.0 \\
+13.1 \\
+5.8 \\
+14.8 \\
+5.6\end{array}$ & $\begin{array}{l}2103 \\
2002 \\
1909 \\
1855 \\
2398 \\
2382 \\
2240 \\
2240\end{array}$ & $\begin{array}{r}+8.7 \\
+0.8 \\
+1.1 \\
-7.5 \\
+13.6 \\
+7.5 \\
+9.0 \\
+0.5\end{array}$ & $\begin{array}{l}27.6 \\
26.6 \\
25.1 \\
23.7 \\
28.5 \\
27.2 \\
28.8 \\
26.4\end{array}$ \\
\hline $\begin{array}{l}\text { January } 30 \\
\text { March } 4 \\
\text { February } 9 \\
\text { March 1 } \\
\text { January } 15 \\
\text { January } 22 \\
\text { January } 19 \\
\text { January } 24 \\
\text { February } 18 \\
\text { February } 26\end{array}$ & $\begin{array}{l}\text { R.L.G. } \\
\text { H.A. } \\
\text { L.W.P. } \\
\text { L.W.P. } \\
\text { M.B. } \\
\text { M.B. } \\
\text { O.M. } \\
\text { O.M. } \\
\text { D.R. } \\
\text { D.R. }\end{array}$ & $\begin{array}{l}47.4 \\
34.9 \\
33.7 \\
30.3 \\
28 . \\
24.5 \\
30.1 \\
32.4 \\
29 . \\
23 .\end{array}$ & $\begin{array}{l}2070 \\
1852 \\
1743 \\
1656 \\
1343 \\
1415 \\
1594 \\
1654 \\
1441 \\
1447\end{array}$ & $\begin{array}{l}2461 \\
1844 \\
1853 \\
1658 \\
1539 \\
1348 \\
1486 \\
1656 \\
1586 \\
1252\end{array}$ & $\begin{array}{r}+18.9 \\
-0.4 \\
+6.6 \\
+0.1 \\
+14.6 \\
-4.7 \\
-6.0 \\
+0.1 \\
+10.8 \\
-13.4\end{array}$ & $\begin{array}{l}2510 \\
1850 \\
1786 \\
1593 \\
1485 \\
1298 \\
1595 \\
1716 \\
1536 \\
1219\end{array}$ & $\begin{array}{r}+21.2 \\
-0.1 \\
+2.5 \\
-3.8 \\
+10.6 \\
-8.3 \\
+0.0 \\
+3.7 \\
+6.6 \\
-15.7\end{array}$ & $\begin{array}{l}29.8 \\
25.1 \\
25.5 \\
24.8 \\
27.3 \\
22.7 \\
23.4 \\
25.7 \\
.27 .0 \\
21.2\end{array}$ \\
\hline
\end{tabular}

rial dealt with by Levine and Marples consisted of observations lasting only several hours. While we are convinced that periods of 10 to 20 minutes give irregular results, it is probable that the method is applicable to periods much shorter than 24 hours.

As in all methods, it is essential to guard against certain errors. In this case it is especially im-

- Fifty-three is the factor obtained from line A, Figure 3 , by dividing 24-hour calories by the corresponding hourly I. L. at any point. portant to train the subject to maintain himself in a comfortable state without feeling cool or warm. Since the sweating mechanism becomes active at only a few degrees above the environmental temperature at which most individuals are comfortable, it is important not to allow the room temperature to rise above $72^{\circ} \mathrm{F}$. In order to know that the subject is trained, it is desirable to insist upon uniform activity during the training period. When under these circumstances consistent I. L.s are obtained, one has evidence that 
TABLE II

Comparison between heat calculated from $I$. $L$. and heat production determined from the calories of the diet corrected for change in weight

\begin{tabular}{|c|c|c|c|c|c|c|}
\hline \multirow[b]{2}{*}{ Subject } & \multirow[b]{2}{*}{ I.L. } & \multicolumn{3}{|c|}{ Heat production } & \multicolumn{2}{|c|}{ Difference } \\
\hline & & $\begin{array}{c}\text { From } \\
\text { diet }\end{array}$ & I.L. $\times 53$ & I.L. X5711 & $\begin{array}{c}\text { Col- } \\
\text { umns } \\
3 \text { and } 4\end{array}$ & $\begin{array}{c}\text { Col- } \\
\text { umns } \\
3 \text { and } 5\end{array}$ \\
\hline & grams & & & & $\begin{array}{l}\text { per } \\
\text { cent }\end{array}$ & $\begin{array}{l}\text { per } \\
\text { cent }\end{array}$ \\
\hline $\begin{array}{l}\text { F.D.J.10 } \\
\text { G.G.10 } \\
\text { T.M. }{ }^{10} \\
\text { R.S. } \\
\text { B.deV. } \\
\text { F.H.W. } \\
\text { F.H.W. } \\
\text { A.W. } \\
\text { R.L.G. } \\
\text { M.P. } \\
\text { M.W. }\end{array}$ & $\begin{array}{l}51.5 \\
30.5 \\
43.1 \\
57.1 \\
50.8 \\
54.3 \\
60.6 \\
68.4 \\
68.0 \\
63.5 \\
60.4\end{array}$ & $\begin{array}{l}2950 \\
1766 \\
2500 \\
2960 \\
2664 \\
2947 \\
3082 \\
3570 \\
3550 \\
3425 \\
3210\end{array}$ & $\begin{array}{l}2730 \\
1615 \\
2285 \\
3030 \\
2690 \\
2878 \\
3212 \\
3625 \\
3640 \\
3365 \\
3200\end{array}$ & $\begin{array}{l}2936 \\
1739 \\
2457\end{array}$ & $\begin{array}{l}-7.5 \\
-8.5 \\
-8.6 \\
+2.4 \\
+1.0 \\
-2.3 \\
+4.2 \\
+1.5 \\
+2.5 \\
-1.8 \\
-0.3\end{array}$ & $\begin{array}{l}-0.5 \\
-1.5 \\
-1.7\end{array}$ \\
\hline
\end{tabular}

the technique is satisfactory. It appears to be true that the tendency to lose 24.5 per cent of the heat by vaporization of water does not exhibit the constancy that is shown by internal temperature. Hence a single period may not follow the rule and consequently reliable prediction of heat from I. L. can be made only when the average I. L. of a series of determinations is used as the basis of calculation.

We have dealt primarily with normal adults. Whether the method is valuable in the study of disease remains to be decided by future work.

\section{SUM MARY}

Twenty-four hour heat production can be satis-

10 Diabetic subjects on low carbohydrate diets.

11 Fifty-seven is the factor (I. W. = I. L.), used for low carbohydrate plans. factorily predicted from the insensible loss of weight. Factors have been derived for use in accordance with the type of diet fed.

\section{BIBLIOGRAPHY}

1. Newburgh, L. H., Johnston, M. W., Lashmet, F. H., and Sheldon, J. M., Further experiences with the measurement of heat production from insensible loss of weight. J. Nutrition, 1937, 13, 203.

2. Levine, S. Z., and Marples, E., The insensible perspiration in infancy and in childhood. Am. J. Dis. Child., 1930, 40, 269.

3. Newburgh, L. H., Wiley, F. H., and Lashmet, F. H., A method for the determination of heat production over long periods of time. J. Clin. Invest., 1931, 10, 703.

4. Wiley, F. H., and Newburgh, L. H., The doubtful nature of "Luxuskonsumption." J. Clin. Invest., 1931, 10, 733.

5. Heller, H., Die quantitativen Beziehungen zwischen Perspiratio insensibilis und Energieumsatz. Ztschr. f. d. ges. exper. Med., 1932, 83, 128.

6. Ginandes, G. J., and Topper, A., Statistical correlation of insensible perspiration and basal metabolism. Am. J. Dis. Child., 1937, 53, 705.

7. Benedict, F. G., and Root, H., Insensible perspiration: Its relation to human physiology and pathology. Arch. Int. Med., 1926, 38, 1.

8. Jores, A., Perspiratio insensibilis. Ztschr. f. d. ges. exper. Med., 1930, 71, 170.

9. Wiley, F. H., and Newburgh, L. H., The relationship between the environment and the basal insensible loss of weight. J. Clin. Invest., 1931, 10, 689.

10. Laszlo, D., and Schurmeyer, A., Perspiratio insensibilis und Grundumsatz. Ztschr. f. klin. Med., 1931, 116, 22.

11. Heller, H., and Schwarz, A., Extrarenale Wasserausscheidung und Stoff wechsel. Ztschr. f. d. ges. exper. Med., 1930, 71, 416. 